\title{
Attitudes and HRM decisions toward older workers in Africa: Exploring contradictions through an empirical study
}

Arménio Rego ${ }^{\mathrm{a}}$ b*, Andreia Vitória ${ }^{\mathrm{c}}$, d, Tânia Ribeiro ${ }^{\mathrm{e}}$, Leonor Ribeiro $^{\mathrm{d}}$, Rui Lourenço-Gil $^{\mathrm{a}}$, Susana Leal ${ }^{\mathrm{f}, \mathrm{g}}$ and Miguel Pina e Cunha ${ }^{\mathrm{h}}$

${ }^{a}$ Católica Porto Business School, Universidade Católica Portuguesa, Porto, Portugal; ${ }^{b}$ Instituto Universitário de Lisboa (ISCTE-IUL), Business Research Unit, Lisboa, Portugal; ${ }^{c}$ Universidade de Aveiro, Aveiro, Portugal; ${ }^{d}$ GOVCOPP - Research Unit on Governance, Competitiveness and Public Policies, Aveiro, Portugal; ${ }^{e} J a s o n$ Associates, Mozambique; ${ }^{f}$ Instituto Politécnico de Santarém, Santarém, Portugal; ${ }^{g}$ Centro de Investigação em Qualidade de Vida, Santarém, Portugal; ${ }^{h}$ Nova School of Business and Ecomomics, Universidade Nova de Lisboa, Lisboa, Portugal.

*Corresponding author

Arménio Rego: arego@porto.ucp.pt

\section{Acknowledgements}

This work was supported by Fundação para a Ciência e a Tecnologia (FCT), grant UID/GES/00315/2013. This work was also partially funded by National Funds through FCT under the project Ref. UID/ECO/00124/2013, and by POR Lisboa under the project LISBOA01-0145-FEDER-007722. 


\title{
Attitudes and HRM Decisions toward Older Workers in Africa: Exploring Contradictions through an Empirical Study ${ }^{1}$
}

\begin{abstract}
We explored the attitudes toward older workers of African versus Portuguese managers, and how these managers make HRM decisions in scenarios involving younger versus older workers. To make cultural, social, and institutional explanations more robust, we also included two samples of students attending Portuguese universities: one sample comprising African students, the other comprising Portuguese ones. The main findings were: (a) a three-factor model (conscientiousness and performance; social capital and generosity; adaptability) of attitudes toward older workers emerged as satisfactory across the four samples; (b) in comparison with the Portuguese participants, African individuals expressed more positive attitudes toward older workers while, at the same time, discriminated against older workers more; (c) the findings were almost identical for both managers and students. Although African individuals showed more positive attitudes toward older workers than did the Portuguese, they made more discriminatory decisions in the HRM scenarios. We suggest that this contradiction may emerge from dualities characterizing Africa.
\end{abstract}

Keywords: ageism; discrimination; managers' attitudes toward older workers; Africa; paradox

\section{Introduction}

Ageism is "a process of systematic stereotyping and of discrimination against people because they are old, just as racism and sexism accomplish this for skin colour and gender" (Butler, 2002, p. 12). Although it can target different ages (including younger people; Bratt, Abrams,

\footnotetext{
${ }^{1}$ We are very grateful for the helpful comments and recommendations of the two anonymous reviewers.
} 
Swift, Vauclair, \& Marques, 2018; Lev, Wurm, \& Ayalon, 2018; Marshall, 2007), ageism toward older people, including older workers, tends to be more pervasive (Fisher, Truxillo, Finkelstein, \& Wallace, 2017; Truxillo, Fraccaroli, Yaldiz, \& Zaniboni, 2017). We focus here on ageism toward older people, which has consequences for how older workers are managed and for the older workers' engagement and for organizational performance (Fineman, 2011; Henkens, 2000; Naegele, De Tavernier, \& Hess, 2018; Van Dalen, Henkens, \& Schippers, 2010)

Although a few studies have included non-Western contexts (e.g., Chiu, Chan, Snape, \& Redman, 2011; Voss, Kornadt, Hess, Fung, \& Rothermund, 2018), the topic has been studied mainly in Western countries (i.e., English-speaking and Western European countries; Levy, \& Macdonald, 2016; Macdonald \& Levy, 2016; North \& Fiske, 2015), and there is metaanalytic evidence (North \& Fiske, 2015) suggesting that attitudes and behaviors toward older workers differ across cultures in ways that somewhat contradict the conventional wisdom that Eastern cultures are more elder-reverent than Western ones. In this article, and considering that the context matters (Bratt et al., 2018; Fisher et al., 2017), we respond to the need to conduct research in the "rest of the world" (Ozkazanç-Pan, 2008), and focus specifically on Portuguese speaking Sub-Saharan African (SSA) countries. Although Africa holds in many ways the same potential that China did a few decades ago (Chironga, Leke, Lund, \& Van Wamelen, 2011), and because seven of the world's 20 fastest growing economies in the next years will possibly be in Africa (Zoogah, Peng, \& Woldu, 2015; see Economist Group, 2013), Kamoche (2011) observed that Africa remains relatively ${ }^{2}$ under-researched in fields such as management, human resources, and organization studies. Khan and Ackers (2004) noted that "established Western employment frames of reference do not represent suitable theoretical frameworks for analysing all the relevant social factors that influence the SSA employment

\footnotetext{
2 In absolute terms, however, the number of publications addressing African management has increased significantly (Kamoche, Chizema, Mellahi, \& Newenham-Kahindi, 2012).
} 
relationship" (p. 1330) and that SSA is a socio-cultural context in which values, beliefs, and actions challenge the notion that Western management practices are universally valid and applicable.

One particular domain in which SSA differs from the West is ageing and how older people/workers are perceived and treated. Africa is characterized by a dual/contradictory social and cultural context (Kamoche, 2011; Zoogah et al., 2015), and this duality may have consequences for managers' attitudes and behaviors toward older workers. In fact, the African societies have different structures compared to Western ones. The extended family system is still common in African countries, where older people play a greater role, within both the family and society (Aboderin, 2004; Aboderin, \& Hoffman, 2015; Makoni, 2008; Oluwabamide \& Eghafona, 2012). In traditional African cultures, older persons are to be respected and are encouraged to actively participate in the affairs of their communities (Mangaliso, 2001). However, Makoni (2008, p. 200) noted that industrialization and the increase in numbers of aging persons may be weakening the robust "traditionally extended family structure", which used to cater to the elderly.

Moreover, Africa is characterized by a "youth bulge" (a "demographic bonus"; Sippel, Kiziak, Woellert, \& Klingholz, 2011), in which the demographic transition (i.e., the population ageing, as initiated decades ago in other contexts) is still in its infancy and probably will remain relatively young for decades (United Nations, 2017; World Economic Forum, 2017). In a "young continent" governed by a "gerontocracy" (Fox, Senbet, \& Simbanegavi, 2016, p. i6), the large cohort of youth entering the labor force faces a major challenge: "youth unemployment in Africa, especially sub-Saharan Africa, has remained stubbornly high" (Chigunta, 2017, p. 433). We thus posit that the "demographic bonus" may be associated with negative biased attitudes and behaviors toward older workers. These 
workers are possibly considered (a) as an obstacle for the entry of young people into the labor market, (b) a "burden" on a "young society", or (c) a segment of population whose traditional values and habits are less compatible with the requirements of a more modern management (Blunt \& Jones, 1992; Dia, 1996; Kamoche, Chizema, Mellahi, \& Newenham-Kahindi, 2012; Khan \& Ackers, 2004; Kiggundu, 1989).

This study explores empirically how SSA managers respond to that ambivalent context. Specifically, it is possible that while (a) some elements of the traditional cultural, social, and institutional context may induce Africans to hold more positive attitudes toward older workers, (b) other elements of the rational-economic western paradigm (Kamoche, 1997; Kamoche et al., 2012) may incline African individuals to prefer working with younger versus older candidates. We follow and expand the work of Rego, Vitória, Tupinambá, Cunha, and Leal (2017), who found that although Portuguese and Brazilian managers acknowledge that older workers have positive qualities, they discriminate against them. We test if the same empirical pattern emerges in SSA and how African managers respond to the ambivalent context mentioned above. The study explores the following question: How do African managers/students make decisions in HRM scenarios involving older versus younger workers/candidates? To make cultural/contextual explanations more robust, we replicate the study with samples of university students from SSA and Portugal (both samples attending Portuguese universities), thus seeking to explore the following questions: In comparison with Portuguese managers/students, are African managers/students more or less discriminatory toward older workers? Are the attitudes of African managers/students more or less positive than those of Portuguese managers/students?

Portuguese managers/students are included because of the following reasons. Portugal is a Western and modern society. Portugal is also a former colonizer of the African countries 
where the African managers/students of our study proceed from. The official language in those countries is Portuguese. The culture of those African countries shares similarities with the Portuguese culture, although they differ (see, e.g., https://www.hofstedeinsights.com/product/compare-countries/). Therefore, comparing managers/students from those African countries with Portuguese managers/students is more conservative than comparing them with managers and students from more culturally distant Western cultures.

Before proceeding, two assumptions are made. First, by "Africa" we mean SSA (Makoni, 2008). Although North Africa and SSA share several similarities (Bentahar, 2011; Sangmpam, 2017), North Africa is predominantly Arab, and most people there identify more with the Middle East than they do with the rest of the continent. Differences between the two sub-regions may be found at the historic, economic, corporate governance, institutional, legal foundations/origins, political, geoecological and anthropological levels (Bentahar, 2011; Hearn, 2015; Sangmpam, 2017). According to Bentahar (2011, p. 4), the distinction between the two sub-regions increased after decolonization, "reflecting the shifting political drives of pan-Arabism and pan-Africanism". Several international institutions include North Africa (together with Middle East) and SSA in different regions (Schwab, 2015). Second, although Africa cannot be considered as socially, culturally, politically, and economically homogeneous (Horwitz, 2015), a certain degree of uniformity in SSA may be identified in terms of industrial development, the ethos of post-independent imperatives for economic growth, and the "African thought system" (Kamoche, 1993, 1997, 2011).

\section{Literature review}

African societies have unique features that affect older people (Kinsella \& Phillips, 2005). Contrasting with the rapidity of ageing in other parts of the developing countries, most of SSA is in an intermediate stage of demographic transition. Ageing has developed more slowly 
in SSA than in developed countries, not because the elderly population has not grown significantly (in fact, it has; see Aboderin \& Hoffman, 2017; United Nations, 2017), but because the fertility rates have been comparatively higher and the percentage of younger people in the demographic structure is also correspondingly high. As Aboderin and Hoffman (2017) pointed out, SSA is and will continue to be the youngest of all world regions.

Such a landscape is framed by contradictory influences. On the one hand, African societies still have different structures compared to Western ones. The extended family system is still common in African countries, where older people play a greater role, both within the family and in the society (Aboderin, 2004; Aboderin \& Hoffman, 2017; Makoni, 2008; Oluwabamide \& Eghafona, 2012). In traditional African cultures, deference to rank and seniority is valued (Horwitz, 2015). An older person is to be respected, is considered wiser and more experienced, and is encouraged to actively participate in the affairs of his/her community.

On the other hand, recent evidence suggests that older African people are significantly discriminated against. The African Union's plan of action on ageing (AU/HelpAge, 2003, p. 5) noted that "old people in Africa are particularly disadvantaged due to lack of social security for their everyday social and economic needs" and that "the care and support by the family and community that was taken for granted in the past" is no longer expectable because social changes "associated with urbanisation and 'development' in general". According to Nhongo (2006), "romanticised notions that all older people are cared for by their families ignore the fact that increasing numbers of older people can no longer rely on traditional patterns of care and support" (p. 3). He pointed out the contradiction: in a continent "famed for the respect and support provided to older people", the discrimination toward them and the denial of their rights "is a worrying phenomenon" (pp. 3-4), and this includes being rare for anyone at age 45 
or above to get employment in the public service as a new entrant (see also Lombard \& Kruger, 2009). Nhongo (2006) concluded that "age discrimination is rife in the African continent" (p. 22). Data from the World Values Survey ${ }^{3}$ suggest that people from Africa versus non-African countries are more likely to agree with statements representing discrimination toward older people (Table 1). Peterson and Ralston (2017) also found that SSA countries have significantly more negative views toward older people than Western countries.

Table 1 about here

In this paper we explore how older workers are perceived and treated by African managers, a topic almost completely absent from the literature. Africa constitutes a "dual context" (Zoogah et al., 2015) in that, while the modern urban context is characterized by relative openness and individualism, and is thus relatively similar to the Western (and former colonizer) context (Horwitz, 2015), the rural setting is characterized by social institutions revolving around the family and communal activities, in which elders enjoy power and status. Moreover, researchers (e.g., Anakwe, 2006; Jackson, 2004) have pointed out that African employees "often behave as though they inhabit two parallel worlds - the world of work and a broader African society" (Kamoche et al., 2012, p. 2830). These dualities make the African context a configuration of exogenous and endogenous stimuli that "interactively influence management of organizations" (Zoogah et al., 2015, p. 12).

Managers are potentially influenced by this duality and thus experience contradictory, or ambivalent, feelings, attitudes, and behaviors. On the one hand, African managers are potentially influenced by the wider communitarian, family, cultural, and institutional context, in which older people play a greater role in the family and society (Aboderin, 2004; Aboderin

\footnotetext{
${ }^{3}$ http://www.worldvaluessurvey.org/wvs.jsp.
} 
\& Hoffman, 2017; Khan \& Ackers, 2004; Lombard \& Kruger, 2009; Makoni, 2008; Oluwabamide \& Eghafona, 2012). Industrialization in much of Africa is relatively recent, and the way of life, including work, is "still largely determined by traditionalism" (Kamoche, 1997, p. 545). The supportive role provided by older people within the family is especially valuable in a context where comprehensive formal welfare systems are mostly absent (Aboderin \& Hoffman, 2015).

On the other hand, it is possible that the African demographic and (un)employment reality as described above (Chigunta, 2017; Fox et al., 2016) fosters negative biased attitudes and behaviors toward older workers, who are possibly considered as an obstacle for the entry of young people into the labor market or as a "burden" on a "young society". While in the highincome regions "projections of aging labor forces coupled with increasingly salient 'successful' or 'active' aging perspectives have intensified emphasis on the importance of later life work", the SSA's population and political-economic agendas "are concerned overwhelmingly with the employment and training needs of the region's youth bulge" (Aboderin \& Hoffman, 2017, p. 388; see also African Union, 2017, and Beard et al., 2012). The possible negative bias emerging from such a context (Naegele et al., 2018) may be reinforced by the very behaviors and attitudes of older workers. Older versus younger workers are more likely influenced (Aboderin \& Hoffman, 2017; Khan \& Ackers, 2004) by more enduring and legitimate traditional institutions and social structures (e.g., extended family clans and religious brotherhoods) that make their relationships with, and their behaviors in, companies less in line with modern HRM practices.

Specifically, the average African worker is burdened with obligations and commitments (e.g., caregiving responsibilities; Aboderin \& Hoffman, 2015, 2017) imposed by the social organizations and institutions at large, and these requirements influence attitudes and 
behaviors toward the rational/economic objectives and policies characterizing formal organizations (Khan \& Ackers, 2004). Khan and Ackers (2004, p. 1333) noted that "Although individuals are keen to enter into waged employment and adapt to the formal regulations and values of modern organizations, they do not consider these formal obligations to have precedence over the obligations and commitments they have as a result of their membership of the surrounding African community". As a consequence, the traditional cultural framework may lead older individuals to consider work as simply instrumental and calculative, an activity to be tolerated in order to make money, and not as central in life nor as a source of satisfying self-actualization needs (Blunt \& Jones, 1992; Delhey, 2010; Inglehart, 1997).

In short, there seems to be a "disconnect" (Dia, 1996) between traditional African values and "transplanted organizational forms and management approaches" (Khan \& Ackers, 2004, p. 1339), and this gap may be wider for older workers, leading managers to see them as less suitable to work within the economically rationalized formal organizations. As Kamoche (1997, p. 544) observed, "it is the West which has continued to supply management ideas to Africa, from colonial times to the present". Thus, it is possible that African managers, mostly educated within the Western mindset and according to Western management and organization theories, see the older workers as bringing traditional values, norms, and attitudes that are undesirable for "modern" management (Blunt \& Jones, 1992; Cooper, 1987; Dia, 1996; Khan \& Ackers, 2004; Kiggundu, 1989).

How do SSA managers respond to these perceived contradictions? What attitudes toward older workers do they hold? Who do they select when they have to choose between an older versus a younger candidate? In comparison with managers from Portugal, a Western country, do SSA managers hold more or less positive attitudes toward older workers? Are SSA 
managers comparatively more or less discriminatory in their HRM decisions? These are questions we seek to answer with this study.

We collected data from African managers (from four Portuguese-speaking SSA countries) and Portuguese managers. To make cultural, social, and institutional explanations more robust (i.e., to explore whether possible differences between the attitudes and behaviors of individuals from Africa versus Portugal toward older workers come from deep, cultural reasons), we also include two samples of students attending Portuguese universities: one sample comprising African students, the other comprising Portuguese ones.

\section{Method}

\section{Samples and procedures}

All participants were invited through an email containing a brief note of encouragement and the link to an online survey supplying the questionnaire. All were informed that their responses would be anonymous. A reminder was sent to all of them two-three weeks later. Five hundred and seventy African managers (working in four SSA countries; $42 \%$ female) and 346 Portuguese managers (working in Portugal; 29\% female) were invited to participate. They were part of the informal network of the first five authors' professional contacts. Six hundred and thirty-seven Portuguese students (59\% female) were also invited to participate. They were attending courses taught by four authors teaching in three Portuguese institutions. To collect data from African university students, we sought the cooperation of the academic services of these three institutions. All of the students $(n=274 ; 44 \%$ female $)$ registered as nationals of African Portuguese-speaking countries were invited to participate. To increase the sample size we asked for the cooperation of scholars (from their professional contacts) 
teaching in two other Portuguese institutions, who invited their African students to participate in the study.

\section{Managers' samples}

One hundred and fifty-four (response rate: 27\%) African middle and top managers (from Angola, Mozambique, Cape Verde, and São Tomé and Príncipe) participated (42\% female; $77 \%$ operating in the services sector, the others in industry). Mean age was 36.9 years (SD: 8.81), and mean job tenure was 6.0 years (SD: 5.39). Five percent had 12 schooling years, $64 \%$ had a university degree, and 31\% had a master's degree or a $\mathrm{PhD}$. Managers operated in Africa and performed a wide range of management jobs, from CEO and general manager to functional manager in fields such as human resources, IT, supply chain, marketing, engineering, law, sales, manufacturing, project management, finance, and accounting.

One hundred and fifty-four (response rate: 39\%) Portuguese middle and top managers participated (25\% female; $67 \%$ operating in the services sector). Mean age was 38.5 years (SD: 5.82), and mean tenure on the job was 7.4 years (SD: 5.64). Two percent had 12 schooling years, $56 \%$ had a university degree, and $42 \%$ had a master's degree or a $\mathrm{PhD}$. Managers operated in Portugal and performed a wide range of management jobs, from CEO and general manager to functional manager in fields such as human resources, IT, supply chain, marketing, engineering, law, sales, manufacturing, project management, finance, and accounting.

\section{Students'samples}

One hundred and eight African university students (from Angola, Mozambique, Cape Verde, Guinea-Bissau, and São Tomé and Príncipe) studying in five Portuguese universities participated (46.3\% female; $16.6 \%$ master students, the others undergraduate students). Mean 
age was 28.4 years (SD: 8.65). Forty-one percent studied management, the others studying engineering (35\%) as well as architecture, biology, mathematics, and psychology (24\%). One hundred and thirty-eight Portuguese students participated (69\% female; $11 \%$ master students, the others undergraduate students). Mean age was 26.4 years (SD: 9.59). Eighty-five percent studied management, the others studying engineering (4\%) and biology, new communication technologies, and mathematics (11\%).

\section{Measures}

\section{Dependent variables}

Four scenarios (Table 2) involving younger versus older candidates were presented to individuals. The first scenario referred to the selection of a younger versus an older individual. While in this scenario only age differed in the description of the two hypothetical workers, the next two scenarios included a characteristic favoring the older worker profile. We considered that the bias against age would be mitigated when additional information (beyond age) about the target was provided (Kite, Stockdale, Whitley, \& Johnson, 2005).

The second scenario related to selecting workers to participate in training, the older worker being described as more motivated to the training. The third scenario was included to test if the managers' attitudes predict their decisions in a situation in which the company, in order to reduce costs, aims to dismiss an older versus a younger worker (the older being described as having better performance). This scenario is included because age discrimination increases in times of economic restructuring (Roscigno et al., 2007), and the literature has suggested that older workers are discriminated against during downsizing (Armstrong-Stassen \& Cattaneo, 2010; Klehe, De Pater, Koen, \& Kira, 2017; Rau \& Adams, 2014). The fourth scenario differed from the first in that the older applicant/worker was now described as a female (the 
younger as being male). As Fineman (2014, p. 1721) observed, "age is gendered. For women, age is potentially a double jeopardy: they often experience age discrimination at a younger age than men".

Table 2 about here

Different ages were attributed to the workers described in the first three scenarios for two reasons. First, we sought to create as much as possible an appearance of verisimilitude in the three scenarios (i.e., using the same ages in all scenarios could reinforce the sense of artificiality in the respondents' mind). Second, the literature is inconsistent regarding what an older worker is (Duncan \& Loretto, 2004; Finkelstein, Ryan, \& King, 2013; Maurer, Barbeite, Weiss, \& Lippstreu, 2008; OECD, 2006; Truxillo, Cadiz, \& Hammer, 2015; Wood, Wilkinson, \& Harcourt, 2008). The same ages were included in the first and fourth scenarios because our aim was to test if, all the other conditions being equal in both candidates, the older one would be more discriminated against for being female.

Before proceeding, it is also important to note that no clear guidelines exist to define the most appropriate age boundaries of different age groups (Finkelstein et al., 2013; Maurer et al., 2008; OECD, 2006). The division into different age groups is arbitrary (Lev, Wurm, \& Ayalon, 2018). What constitutes an older worker may vary from sector to sector (Wood et al., 2008). People in general have different ideas about the age threshold that defines an older worker (Duncan \& Loretto, 2004), and the concept seems to be evolving as people live and work longer (Truxillo et al., 2015, 2017). In this research, to reduce the risks of common method variance (mainly consistency bias; Podsakoff, MacKenzie, Lee, \& Podsakoff, 2003), and because specific ages are included in the scenarios used for measuring dependent variables, we do not include any threshold age in the scales measuring the managers' attitudes toward "older workers". 
Based on Rego et al. (2018) we operationalized "the propensity to discriminate against older workers" as the number of times/scenarios a manager prefers the younger versus the older worker. It is a formative construct (Coltman, Devinney, Midgley, \& Venaik, 2008) representing how the participants tend to select the younger versus the older worker across different scenarios/situations.

\section{Attitudes toward older workers}

The attitudes toward older workers were measured through 20 items suggested by Rego et al. (2017), embracing five dimensions: (1) adaptability, (2) value of older workers' competencies for organizations, (3) organizational conscientiousness, (4) social capital and generosity, and (5) performance. Those authors found that the five-factor model is valid across Portuguese and Brazilian samples. We performed confirmatory factor analyses (CFA) to test the fivefactor model suggested by those authors. The model fitted the data well for the Portuguese samples (managers and students), while it did not fit the data satisfactorily for the African samples. Thus, in order to obtain commensurability across the four samples, we carried out several exploratory analyses (principal component analysis). After removing eight items with high cross-loadings or for which the respective factor presented very low reliability $(<0.60)$, a three-factor model with 12 items emerged (items in Table 3), explaining 58.05\% of variance. The first dimension, "Conscientiousness and performance" represents behaviors related to both in-role and extra-role performance. In the original five-factor model (Rego et al., 2017), these items loaded onto two different factors (conscientiousness and performance). The contents of the other two dimensions are similar to those suggested by Rego et al. (2017). The second and third dimensions represent "social capital and generosity" and "adaptability", respectively. 
CFAs upon the data of each sample (LISREL; maximum likelihood estimation method) tested the three-factor model. A reasonably well-fitted model emerged for the four samples (Table 3), the fit indices being less satisfactory for the African students' sample. All Cronbach Alphas except one (0.66) are higher than 0.70. A multi-group CFA (MGCFA; model \#1, unconstrained) was carried out to assess the validity of the measurement instrument across the four samples. The fit indices of the unconstrained model are satisfactory $\left(\chi^{2}(204)=291.71\right.$; RMSEA: 0.06; CFI: 0.96). For testing the invariance of factor loadings across samples, equality constraints were imposed to all factor loadings. The resulting model fits the data satisfactorily $\left(\chi^{2}{ }_{(231)}=315.85\right.$; RMSEA: 0.05; CFI: 0.96). A nonsignificant difference between models \#1 and \#2 $\left(\Delta \chi^{2}(\Delta \mathrm{df})=24.14_{(27)}, p=0.62\right)$ suggests equality of factor loadings across the four samples (i.e., the constructs manifest the same way in each group; Kline, 2011). Thus, the findings suggest the construct level invariance across both samples.

Table 3 about here

\section{Findings}

Table 4 shows that across the four samples the attitude of "conscientiousness and performance" is positive (i.e., positioned in the upper third of the 7-point scale), while the attitude of "social capital and generosity" is moderately positive, and the attitude of "adaptability" tends to be comparatively modest (with the exception of African students). Table 4 also shows that older workers tend to be discriminated against in HRM decisions. In fact, when both the younger and the older candidates are described in the same way (scenario \#1), a significant majority of individuals (managers and students) selects the older one (binomial test: proportions are different from 50\% in the four samples; $p<0.05$ ). Discrimination is not higher when the older worker is described as a female (scenario \#4). Additional evidence of discrimination is that, even when the older worker is described as 
having more positive qualities (scenarios \# 2 and \#3), a significant number of participants in the study preferred the younger worker.

Table 4 about here

The data presented in Table 4 also suggest that the attitudes toward older workers of the African individuals (both managers and students) tend to be more positive than those of the Portuguese participants, but the effect sizes are small/medium $(0.25$ to 0.57$)$ or even very small (0.02 and 0.14; Cohen, 1988). One possible explanation could be differences (in terms of age, gender, schooling, tenure, background, and sector) between the African and the Portuguese samples. For this reason, we tested the predictive value of being African versus Portuguese for the three attitudes, and the overall attitude (a formative measure; Coltman, Devinney, Midgley, \& Venaik, 2008), after controlling gender and age (all participants), being a student of management (students), and schooling years, job tenure, and sector (managers). The findings (Table 5) indicate that being African versus Portuguese predicts a small amount of unique variance of one attitude of managers (social capital and generosity) and two attitudes of students (social capital and generosity, and adaptability). African participants hold more positive attitudes toward older workers than do the Portuguese, the effective size being small (0.02 and 0.06, for the managers' and the students' samples, respectively) for predicting the overall attitude toward older workers.

Table 5 about here

The findings (Table 4) also indicate that the percentage of individuals who select the younger worker is always higher within the African samples than within the Portuguese samples. The findings presented at the bottom of Table 4 also show that the propensity of African versus Portuguese participants (both managers and students) to discriminate against older workers is 
significantly higher. Among the African versus the Portuguese managers, $44.1 \%$ versus $9.7 \%$ $(\mathrm{z}=6.49, \mathrm{p}<0.001$ ) selected the younger worker across three or four scenarios (findings not shown in Table 4). Among the African versus the Portuguese students, $43.5 \%$ versus $22.5 \%$ ( $=3.52, \mathrm{p}<0.001)$ selected the younger worker across three or four scenarios. As a robustness check, we also tested if being African versus being Portuguese predicts the decisions in the four scenarios. Hierarchical regression analyses (binary logistic) were carried out. Table 6 shows that after including control variables $\left(1^{\text {st }}\right.$ step, not shown $)$ and the attitudes toward older workers, being African versus being Portuguese predicts unique variance of the managers' decisions in the four scenarios and their propensity to discriminate against older workers, the effect size being medium. These findings are replicated among the student participants for the first three scenarios, although the amounts of predictive unique variance are lower.

In short, although the African participants tend to have more positive attitudes toward older workers than the Portuguese (see the comparison between the mean scores included in the upper part of Table 4; see also, in Table 5, the coefficients of "Being African versus Portuguese"), the African participants discriminate against older workers more (see the middle and bottom parts of Table 4, and the coefficient of "Being African versus Portuguese" in the last column of Table 6). Note that although a few differences are not significant, the pattern is consistent across attitudes, behaviors, and samples.

Table 6 about here

Before proceeding it is worth noting that participants' age predicts a small portion of unique variance of the three managers' attitudinal dimensions, and of one students' attitudinal dimension (Table 5): older participants demonstrate more positive attitudes toward older workers. The empirical pattern is less clear about predicting the decisions in the scenarios. In 
fact, although older participants are more likely to select older workers in two scenarios, they are less likely to select older workers in the other scenario (Table 6). The low predictive values and the opposite directions of the predictive value for different scenarios help to explain why participants' age does not predict their propensity to discriminate against older workers (last column of Table 6).

\section{Discussion and conclusions}

Three main findings are worth discussing. First, the five-factor model proposed by Rego et al. (2017) to measure the attitudes toward older workers is not validated in our sample of African managers and students. It is possible that Africa presents idiosyncratic social, cultural, and economic challenges that induce individuals to see older workers through specific lenses that differ from those used in other contexts. For example, while the Portuguese and Brazilian managers who participated in the study by Rego et al. (2017), as well as the Portuguese participants in the current study, distinguish between in-role (i.e., dimension named as "performance") and extra-role performance ("organizational conscientiousness"), this distinction is not found among the African participants in the current investigation. One possibility is that autocratic and transactional leadership, possibly more frequent in Africa (Beugré \& Offodile, 2001; Bottger, Hallein, \& Yetto, 1985; Jallow, 2014), reduces the workers' discretion to adopt extra-role behaviors, discretionary by definition (Podsakoff, Whiting, Podsakoff, \& Blume, 2009), and the boundaries between in-role and extra-role behaviors are blurred. However, the evidence that the three-factor model suggested here is valid across Portuguese and African participants also indicates that older workers are seen through similar perspectives in different contexts. Both emic and etic approaches are thus recommendable to interpret the attitudes toward older workers as espoused by individuals 
from different cultural contexts. Future studies may thus explore if Rego et al.'s measure is worth being revised to improve cross-cultural validity.

The second most important finding is that, although individuals see older workers as endowed with positive qualities, a significant number of participants were inclined to discriminate against them, i.e. they prefer to select a younger worker even when the older one is described as having better qualities (from a managerial point of view). This empirical pattern was found in both the Portuguese and the African samples, and among both managers and university students. The findings are consistent with those reported in Western countries, where positive attitudes toward older workers may coexist with discriminatory decisions against them (Loreto \& White, 2006a, 2006b; Rego et al., 2017; Truxillo et al., 2015). Thus, the finding indicates that ageism is not exclusive to Western countries with ageing populations.

A third important finding, perhaps the most significant considering the scarcity of studies about the topic in Africa, portrays a paradoxical conceptual landscape: compared with the Portuguese participants, African managers and students have slightly more positive attitudes toward older workers, while at the same time discriminate against older workers more. It seems that African managers respond to the ambivalent context (as described in the literature review) with an ambivalent stance. On the one hand, some elements of the traditional cultural, social, and institutional context may induce African individuals to hold more positive attitudes toward older workers. On the other hand, other elements of the rational-economic Western paradigm (Kamoche, 1997; Kamoche et al., 2012) may incline African participants to prefer working with younger versus older candidates.

It is possible that, influenced by modern Western theories and approaches (i.e., "shaped and influenced by colonial ideology and capitalist modes of production”; Khan and Ackers, 2004, p. 1332), African managers align with philosophical perspectives that see the traditional 
African social system (in which the elderly are respected, and older workers are less likely to assume the organizational role as central in their lives) as perverse to good management practices (Dia, 1996; Khan \& Ackers, 2004; Kiggundu, 1989). The fact that the empirical pattern is similar across managers and students suggests that the phenomenon has deep roots in cultural, social, and institutional features of Africa.

It is possible that the findings reflect an incompatibility between elements of the indigenous "African social system" and the "transplanted management paradigms used to manage African workers" (Khan \& Ackers, 2004, p. 1344). Therefore, our study contributes to the paradox literature (Putnam, Fairhurst, \& Banghart, 2016; Schad, Lewis, Raisch, \& Smith, 2016) in two main ways. First, the study suggests that paradoxes pervade multiple sociocultural and economic contexts. Second, the study also indicates that idiosyncratic paradoxes may unfold in different contexts. As Cunha, Fortes, Gomes, Rego, and Rodrigues (2016, p. 3) concluded in a study on ambidextrous leadership and paradoxes in Angola, "Cultural, economic and institutional idiosyncrasies of developing countries may produce paradoxical demands and challenges not identified in other contexts". Future research may study other idiosyncratic (management and organizational) paradoxes of the African context. Considering that our interpretation of the findings is partly speculative, future studies may also measure the managers' values (e.g., Schwartz, 1994) and explore whether and how their (paradoxical) values profiles explain their (paradoxical) attitudes and discriminatory behaviors.

Two additional comments are relevant. First, our findings suggest that older versus younger participants tend to hold more positive attitudes toward older workers. The fact that these findings emerge in both the managers' and students' samples and in both the African and Portuguese samples is consistent with the "preponderant" evidence (Kite et al., 2005, p. 247; see also Chiu et al., 2011, and Rego et al., 2018) that older people have more positive 
attitudes toward older adults than do younger people. The evidence may be explained by ingroup and intergroup biases emerging from similarity-attraction, social identity, and selfcategorization effects (Truxillo et al., 2017). The findings must, however, be read with caution, because older participants are not necessarily more inclined to discriminate against older workers (Table 6). Thus, future studies may explore the topic in a granular way to understand, for example, why and in which conditions/contexts the attitudes toward older workers turn into more or less discriminatory behaviors.

Second, while our findings point out differences between African and Portuguese participants (although the former have more positive attitudes toward older workers, they discriminate against them more), they also corroborate, to some extent, literature suggesting that previous positive attitudes toward older workers also exist (Finkelstein et al., 2013; Posthuma \& Campion, 2009; Truxillo et al., 2017). Across our four samples (Table 4), while the attitude of "adaptability" tends to be comparatively modest, the attitude of "conscientiousness and performance" is positive. Therefore, our work suggests that studying attitudes toward older workers and discrimination against older workers requires adopting both local and crosscultural lenses.

\section{Limitations and future studies}

The study is not exempt from limitations, and future studies are necessary to clarify issues uncovered by our research. First, only individuals from Portuguese-speaking SSA countries and from Portugal were considered. Neither do the Portuguese-speaking SSA countries represent Africa, nor does Portugal represent the West. In spite of a certain degree of uniformity among SSA, the African "thought system" (Kamoche, 1993, 1997, 2011) and the cultural, social, and institutional context is not a homogeneous monolith, and particularities in each country are likely (see, e.g., the expression "racism against the elderly" identified by 
Peters, 2015). Moreover, managers from the same African country may have different ethnic origins, and these differences may affect their attitudes and behaviors toward older workers. Future studies could thus include data about the ethnic origins of the participants, data from other African countries, as well as data from other Western countries and other continents. One relevant question to be explored in future studies is whether the individuals from Angloor Franco-African countries differ from those from Portuguese-speaking African countries. It is possible, for example, that attitudes toward older workers of people from a more masculine and individualistic country such as South-Africa differ from attitudes of people from Mozambique, a country that scores lower in these two cultural dimensions (see https://geerthofstede.com).

Second, future studies may include larger samples and compare managers operating in different organizational contexts, sectors, and hierarchical levels, and compare students from different backgrounds. Future studies may also compare managers from public versus the private sector (e.g., are managers from the private sector less age biased because of the market context in which they operate?)

The third limitation is that the study includes convenience samples, which may have several consequences for the validity of the findings. For example, the managers' mean age was below 40 years (37 and 39 for the African and the Portuguese managers, respectively). Future studies may include a larger number of older managers. All African students included in this research were affiliated with Portuguese universities. They tend to be privileged individuals who are able to study abroad, in contrast with other Africans who continue to study in their home countries or in neighboring African countries. It is likely that these particularities favor specific attitudinal and behavioral patterns. The way samples were collected may have been affected by potential researchers' biases and demand characteristics. Future studies may adopt 
a different approach to data collection. The characteristics of the African managers' sample may be particularly biased in that almost all managers, beyond having been selected from within the informal network of the authors' professional contacts, had studied abroad, mainly in Portugal. Future studies could compare managers who studied abroad and had international experience with those having only local experiences.

Fourth, the scenarios used to measure behavioral variables cover a reduced number of managers' decisions toward older workers. Future studies could include scenarios involving other, more complex decisions. Fifth, our study involved decisions within hypothetical instead of real situations. Future studies could consider real situations, rather than hypothetical ones, and test how managers actually react toward that reality. It is also important to note that the use of different ages across the scenarios constitutes a "double edged sword": although it has the advantages discussed in the Measures' sub-section, it weakens comparisons across scenarios ${ }^{4}$. Future studies may explore this issue (e.g., does the variation in the age of the older versus younger workers described in a specific scenario affect the participants' reactions?). Sixth, the instrument for measuring the attitudes toward older workers covers a limited range of dimensions. Future studies could continue to explore the issue via the inclusion of attitudinal dimensions (e.g., intellectual abilities and ethical skills) missing from Rego et al.'s (2017) framework.

\section{Concluding remarks}

Our study answers a call by Zoogah et al. (2015), who noted that Africa has remained essentially off researchers' radar screens. The findings corroborate those of Kamoche (2011, p. 1), who argued that "it is not surprising that Africa is often cast as a land of contradiction, unrealized", and Walsh's (2015, p. 1) observation that "Africa remains a complex place" -

\footnotetext{
${ }^{4}$ We are grateful to the anonymous reviewer who pointed out this limitation.
} 
possibly a note with global validity. The study contributes to a better understanding of this under-researched, complex, and nuanced context, regarding a topic that, in the coming years will become increasingly important: ageing and ageism in Africa.

The fact that older people still represent a small proportion of the population in Africa may lead policy makers, citizens, and managers to consider that other more urgent issues rather than older workers' discrimination need to be addressed (Aboderin \& Hoffman, 2017; African Union, 2017; Beard et al., 2012; Nhongo, 2006). However, ageist behaviors may clash with the traditional African social system and mindset. This may have negative consequences for the legitimacy of companies within communities and the whole society. It is known (Fineman, 2011; Loretto, Duncan, \& White, 2000; Rego et al., 2017) that ageist biases and stereotypes in workplaces lead to conflicts, misunderstandings, failures in cooperation and communication between older and younger organizational members, and to an underutilization of older workers' capacities, with perverse consequences for the targeted workers as well as for the team and organizational performance. Within a global context characterized by an increasing number of open economies, the misalignment between the management practices and the African idiosyncrasies may make it difficult for companies operating in Africa to remain competitive. Considering that Sub-Saharan Africa is the region with the largest gap in human capital development and the lowest human capital index (World Economic Forum, 2017), exploring possible managerial sources of such a gap is a valuable endeavor. Discrimination against older workers is a possible source. According to Naegele et al. (2018, p. 74), "understanding the sources of age discrimination at the workplace is the first step in repelling it". Grounded in the notion that the future of "HR is RH" (i.e., respect for humanity) at work (Cleveland, Byrne, \& Cavanagh, 2015), this study contributes to such an important endeavor. 


\section{References}

Aboderin, I. (2004). Modernization and ageing theory revisited: Current explanations of recent developing world and historical Western shifts in material family support for older people. Ageing \& Society, 24, 29-50.

Aboderin, I. \& Hoffman, J. (2015). Families, intergenerational bonds, and aging in SubSaharan Africa. Canadian Journal on Aging/La Revue Canadienne du Vieillissement, 34(3), 282-289.

Aboderin, I. \& Hoffman, J. (2017). Research debate on 'Older careers and work' in SubSaharan Africa? Current gaps and future frames. Journal of Cross-Cultural Gerontology, 32(3), 387-393.

African Union (AU). (2017). AU roadmap on harnessing the demographic dividend through investments in youth. Addis Ababa: African Union.

African Union and HelpAge International (AU/HelpAge). (2003). AU policy framework and plan of action on aging. Kenya: HelpAge International Nairobi.

Anakwe, U.P. (2002). Human Resource Management Practices in Nigeria: Challenges and Insights. International Journal of Human Resource Management Journal, 13, 10421059.

Armstrong-Stassen, M. \& Cattaneo, J. (2010). The effect of downsizing on organizational practices targeting older workers. Journal of Management Development, 29(4), 344 363.

Beard, J., Biggs, S., Bloom, D. E., Fried, L. P., Hogan, P., \& Kalache, A. (Eds.). (2012). Global population ageing: Peril or promise? Geneva, Switzerland: World Economic Forum.

Bentahar, Z. (2011). Continental drift: The disjunction of North and Sub-Saharan Africa. Research in African Literatures, 42(1), 1-13. 
Beugré, C. D. \& Offodile, O. F. (2001). Managing for organizational effectiveness in subSaharan Africa: A culture-fit model. The International Journal of Human Resource Management, 12(4), 535-550.

Blunt, P. \& Jones, M.L. (1992). Managing organisations in Africa. Berlin: de Gruyter.

Bottger, P. C., Hallein, I. H., \& Yetto, P. W. (1985). A cross-national study of leadership: Participation as a function of problem structure and leader power. Journal of Management Studies, 22, 358-368.

Bratt, C., Abrams, D., Swift, H. J., Vauclair, C.-M., \& Marques, S. (2018). Perceived age discrimination across age in Europe: From an ageing society to a society for all ages. Developmental Psychology, 54(1), 167-180.

Butler, R. N. (2002). Why survive? Being old in America. Baltimore, MD: The Johns Hopkins University Press.

Chigunta, F. (2017). Entrepreneurship as a possible solution to youth unemployment in Africa. In T. Skelton, T. Abebe, \& J. Waters (Eds.), Laboring and learning. Geographies of children and young people (vol. 10, pp. 433-451). Singapore: Springer.

Chironga, M., Leke, A, Lund, S., \& van Wamelen, A. (2011). Cracking the next growth market: Africa. Harvard Business Review, 89(5), 117-123.

Chiu, W., A. Chan, E. Snape, \& T. Redman (2001). Age stereotypes and discriminatory attitudes towards older workers: An East-West comparison. Human Relations, 54(5), 101-133.

Cleveland, J. N., Byrne, Z. S., \& Cavanagh, T. M. (2015). The future of HR is RH: Respect for humanity at work. Human Resource Management Review, 25(2), 141-161.

Cohen, J. (1988). Statistical power analysis for the behavioral sciences (2nd ed.). Hillsdale: Lawrence Erlbaum. 
Coltman T., Devinney, T. M., Midgley, D. F., \& Venaik, S. (2008). Formative versus reflective measurement models: Two applications of formative measurement. Journal of Business Research, 61 1250-1262.

Cunha, M. P., Fortes, A., Gomes, E., Rego, A., \& Rodrigues, F. (2016). Ambidextrous leadership, paradox and contingency: Evidence from Angola. International Journal of Human Resource Management. DOI: 10.1080/09585192.2016.1201125

Delhey, J. (2010). From materialist to post-materialist happiness? National affluence and determinants of life satisfaction in cross-national perspective. Social Indicators Research, 97(1), 65-84.

Dia, M. (1996). Africa's management in the 1990s and beyond: Reconciling indigenous and transplanted institutions. Washington, DC: World Bank.

Duncan, C. \& Loretto, V. (2004). Never the right age? Gender and age-based discrimination in employment. Gender, Work and Organization, 11(1), 95-115.

Economist Group. (2013). January. The world in 2013. London.

Fineman, S. (2011). Organizing age. Oxford: Oxford University Press.

Fineman, S. (2014). Age matters. Organization Studies, 35(11), 1719-1723.

Finkelstein, L. M., Ryan, K. M., \& King, E. B. (2013). What do the young (old) people think of me? Content and accuracy of age-based metastereotypes. European Journal of Work and Organizational Psychology, 22(6), 633-657.

Fisher, G. G., Truxillo, D. M., Finkelstein, L. M., \& Wallace, L. E. (2017). Age discrimination: Potential for adverse impact and differential prediction related to age. Human Resource Management Review, 27(2), 316-327.

Fox, L., Senbet, L. W., \& Simbanegavi, W. (2016). Youth employment in Sub-Saharan Africa: challenges, constraints and opportunities. Journal of African Economies, 25(suppl. 1), i3-i15. 
Hearn, B. (2015). Institutional influences on board composition of international joint venture firms listing on emerging stock exchanges: Evidence from Africa. Journal of World Business, 50(1), 205-219.

Henkens, K. (2000). Supervisors' attitudes about early retirement of subordinates. Journal of Applied Social Psychology, 30, 833-852.

Horwitz, F. (2015). Human resources management in multinational companies in Africa: a systematic literature review. The International Journal of Human Resource Management, 26(21), 2786-2809.

Inglehart, R. (1997). Modernization and postmodernization. Cultural, economic, and political change in 43 societies. Princeton: Princeton University Press.

Jackson, T. (2004). Management and Change in Africa: A Cross-Cultural Perspective. London: Routledge.

Jallow, B. G. (2014). Leadership in postcolonial Africa: An introduction. In B. G. Jallow (Ed.), Leadership in postcolonial Africa: Trends transformed by independence (pp. 126). New York: Palgrave Macmillan.

Kamoche, K. (1993). Toward a Model of HRM in Africa. In J. B. Shaw, P. S. Kirkbride, K. M. Rowland, \& G. R. Ferris (Eds.) Research in Personnel and Human Resource Management (pp. 259-78). Greenwich, CT: JAI Press.

Kamoche, K. (1997). Managing human resources in Africa: Strategic, organizational and epistemological issues. International Business Review, 6, 537-558.

Kamoche, K. (2011). Contemporary developments in the management of human resources in Africa. Journal of World Business, 46(1), 1-4.

Kamoche, K., Chizema, A., Mellahi, K., \& Newenham-Kahindi, A. (2012). New directions in the management of human resources in Africa. The International Journal of Human Resource Management, 23(14), 2825-2834. 
Khan, A. S. \& Ackers, P. (2004). Neo-pluralism as a theoretical framework for understanding HRM in sub-Saharan Africa. The International Journal of Human Resource Management, 15(7), 1330-1353.

Kiggundu, M. N. (1989). Managing organizations in developing countries: An operational and strategic approach. Hartford, CT: Kumarian Press.

Kinsella, K. \& Phillips, D. R. (2005). Global aging: The challenge of success. Population Bulletin, 60(1), 1-40.

Kite, M. E., Stockdale, G. D., Whitley, Jr., B. E., \& Johnson, B. T. (2005). Attitudes toward younger and older adults: An updated meta-analytic review. Journal of Social Issues, 61(2), 241-266.

Klehe, U. C., De Pater, I. E., Koen, J., \& Kira, M. (2018). Too old to tango? Job loss and job search among older workers. In U.-C. Klehe \& E. A. J. van Hooft (Eds.), The Oxford Handbook of Job Loss and Job Search (pp. 433.463). Oxford: Oxford University Press.

Kline, R. B. (2011). Principles and practice of structural equation modelling. New York: The Guilford Press.

Lev, S., Wurm, S., \& Ayalon, L. (2018). Origins of ageism at the individual level. In Ayalon, L. \& Tesch-Römer, C. (Eds), Contemporary perspectives on ageism (pp. 51-72). Cham: Springer.

Levy, S. R. \& Macdonald, J. L. (2016). Progress on understanding ageism. Journal of Social Issues, 72(1), 5-25.

Lombard, A. \& Kruger, E. (2009). Older persons: the case of South Africa. Ageing International, 34, 119-135.

Loretto, W. \& White, P. (2006a). Employers' attitudes, practices and policies towards older workers. Human Resource Management Journal, 16(3), 313-330. 
Loretto, W. \& White, P. (2006b). Population ageing and older workers: employers' perceptions, attitudes and policies. Population, Space and Place, 12(5), 341-352.

Loretto, W., Duncan, C., \& White, P. J. (2000). Ageism and employment: controversies, ambiguities and younger people's perceptions. Ageing and Society, 20, 279-302.

Makoni, S. (2008). Aging in Africa: A critical review. Journal of Cross Cultural Gerontology, 23, 199-209.

Mangaliso, M. P. (2001). Building competitive advantage from Ubuntu: Management lessons from South Africa. Academy of Management Perspectives, 15(3), 23-33.

Marshall, V. W. (2007). Advancing the sociology of ageism. Social Forces, 86(1), 257-264.

Maurer, T. D., Barbeite, F. G., Weiss, E. M., \& Lippstreu, M. (2008). New measures of stereotypical beliefs about older workers' ability and desire for development. Journal of Managerial Psychology, 23(4), 395-418.

Macdonald, J. L. \& Levy, S. R. (2016). Ageism in the workplace: The role of psychosocial factors in predicting job satisfaction, commitment, and engagement. Journal of Social Issues, 72(1), 169-190.

Naegele, L., De Tavernier, W., \& Hess, M. (2018). Work environment and the origin of ageism. In Ayalon, L., \& Tesch-Römer, C. (Eds.). Contemporary perspectives on ageism (pp. 73-90). Cham: Springer.

Nhongo, T. M. (2006). Age discrimination in Africa. Paper presented at the International Federation on Ageing Conference, Copenhagen, 30th May - 2nd June.

North, M. S. \& Fiske, S. T. (2015). Modern attitudes toward older adults in the aging world: A cross-cultural meta-analysis. Psychological Bulletin, 141(5), 993-1021.

OECD. (2006). Live longer, work longer. Paris: OECD Publishing.

Oliveira, E. \& Cabral-Cardoso, C. (2017). Older workers' representation and age-based stereotype threats in the workplace. Journal of Managerial Psychology, 32(3), 254-268. 
Oluwabamide, A. J. \& Eghafona, K.A (2012). Addressing the challenges of ageing in Africa. Anthropologist, 14(1), 61-66.

Ozkazanç-Pan, B. (2008). International management research meets the "rest of the world". Academy of Management Review, 33(4), 964-974.

Peters, C. (2015). Racism and ethnic relations in the Portuguese-speaking world. In F. Bethencourt \& A. Pearce (Eds.). The English Historical Review, 130(543), 509-511.

Peterson, L. \& Ralston, M. (2017). Valued elders or societal burden: Cross-national attitudes toward older adults. International Sociology, 32(6), 731-754.

Podsakoff, N. P., Whiting, S. W., Podsakoff, P. M., \& Blume, B. D. (2009). Individual and organizational-level consequences of organizational citizenship behaviors: A metaanalysis. Journal of Applied Psychology, 94, 122-141.

Podsakoff, P.M., MacKenzie, S.B., Lee, J., \& Podsakoff, N.P. (2003). Common method biases in behavioral research: A critical review of the literature and recommended remedies. Journal of Applied Psychology, 88(5), 879-903.

Posthuma, R. A. \& Campion, M. A. (2009). Age stereotypes in the workplace: Common stereotypes, moderators, and future research directions. Journal of Management, 35(1), 158-188.

Putnam, L. L., Fairhurst, G. T., \& Banghart, S. (2016). Contradictions, dialectics, and paradoxes in organizations: A constitutive approach. Academy of Management Annals, $10(1), 65-171$.

Rau, B. L. \& Adams, G. A. (2014). Recruiting older workers: Realities and needs of the future workforce. In K. Y. T. Yiy \& D. M. Cable (Eds.), The Oxford handbook of recruitment (pp. 88-109). New York: Oxford University Press. 
Rego, A., Vitória, A., Tupinambá, A., Cunha, M. P., \& Leal, S. (2017). Developing and validating an instrument for measuring managers' attitudes toward older workers. International Journal of Human Resource Management, 28(13), 1866-1899.

Rego, A., Vitória, A., Tupinambá, A., Reis Júnior, D., Reis, D., Cunha, M. P., \& LourençoGil, R. (2018). Brazilian managers' ageism: A multiplex perspective. International Journal of Manpower, 39(3), 414-433.

Roscigno, V. J., Mong, S., Byron, R., \& Tester, G. (2007). Age discrimination, social closure and employment. Social Forces, 86(1), 313-334.

Sangmpam, S. N. (2017). Ethnicities and tribes in Sub-Saharan Africa. Cham: Switzerland: Palgrave/MacMillan.

Schad, J., Lewis, M. W., Raisch, S., \& Smith, W. K. (2016). Paradox research in management science: Looking back to move forward. The Academy of Management Annals, 10(1), 564.

Schwab, K. (2015). The Global Competitiveness Index 2015-2016. World Economic Forum.

Schwartz, S. H. (1994). Are there universal aspects in the structure and contents of human values? Journal of Social Issues, 50(4), 19-45.

Sippel, L., Kiziak, T., Woellert, F., \& Klingholz, R. (2011). Africa's demographic challenges: How a young population can make development possible. Berlin: Berlin Institute for Population and Development.

Truxillo, D. M., Cadiz, D. M., \& Hammer, L. B. (2015). Supporting the aging workforce: A review and recommendations for workplace intervention research. Annual Review of Organizational Psychology and Organizational Behavior, 2, 351-381.

United Nations. (2017). World population prospects - Key findings \& advance tables, 2017 Revision. New York: Department of Economic and Social Affairs, Population Division, United Nations. 
van Dalen, H. P., Henkens, K., \& Schippers, J. (2010). Productivity of older workers: Perceptions of employers and employees. Population and Development Review, 36(2), 309-333.

Voss, P., Kornadt, A. E., Hess, T. M., Fung, H. H., \& Rothermund, K. (2018). A world of difference? Domain-specific views on aging in China, the US, and Germany. Psychology and Aging, 33(4), 595-606.

Walsh, J. P. (2015). Organization and management scholarship in and for Africa... and the world. Academy of Management Perspectives, 29(1), 1-6.

Wood, G., Wilkinson, A., \& Harcourt, M. (2008). Age discrimination and working life: Perspectives and contestations - a review of the contemporary literature. International Journal of Management Reviews, 10(4), 425-442.

World Economic Forum (2017). The human capital report 2017. World Economic Forum.

Zoogah, D. B., Peng, M. W., \& Woldu, H. (2015). Institutions, resources, and organizational effectiveness in Africa. Academy of Management Perspectives, 29(1), 7-31. 
Table 1. How older people are seen in the World Values Survey (wave \#6, 2015)

\begin{tabular}{|c|c|c|c|c|}
\hline & $\begin{array}{l}\text { Whole sample } \\
\text { (n=60 countries) }\end{array}$ & $\begin{array}{c}\text { Non-African } \\
\text { countries } \\
(n=50)\end{array}$ & $\begin{array}{l}\text { African } \\
\text { countries } \\
\text { (a) } \\
(\mathrm{n}=10)\end{array}$ & $\begin{array}{c}\text { Sub-Saharan } \\
\text { countries } \\
\text { (b) } \\
(\mathrm{n}=8)\end{array}$ \\
\hline \multicolumn{5}{|c|}{ Percentage of people who agree or strongly agree with the following statements } \\
\hline $\begin{array}{l}\text { Older people get more than their fair share } \\
\text { from the government }\end{array}$ & $\begin{array}{c}27.7 \% \\
(22607 \text { in } \\
81515)\end{array}$ & $\begin{array}{c}24.6 \% \\
(16045 \text { in } \\
65271)\end{array}$ & $\begin{array}{c}40.4 \% \\
(6563 \text { in } 16244)\end{array}$ & $\begin{array}{c}40.9 \% \\
(5188 \text { in 12694) }\end{array}$ \\
\hline Older people are a burden on society & $\begin{array}{c}18.1 \% \\
(15129 \text { in } \\
83732)\end{array}$ & $\begin{array}{c}15.8 \% \\
(10638 \text { in } \\
67190)\end{array}$ & $\begin{array}{c}27.1 \% \\
(4490 \text { in } 16543)\end{array}$ & $\begin{array}{c}30.0 \% \\
(3881 \text { in } 12956)\end{array}$ \\
\hline $\begin{array}{l}\text { Companies that employ young people } \\
\text { perform better than those that employ } \\
\text { people of different ages }\end{array}$ & $\begin{array}{c}44.4 \% \\
(35813 \text { in } \\
80673)\end{array}$ & $\begin{array}{c}39.5 \% \\
(25525 \text { in } \\
64614)\end{array}$ & $\begin{array}{c}62.3 \% \\
(10288 \text { in } \\
16059)\end{array}$ & $\begin{array}{c}64.9 \% \\
(8147 \text { in } 12561)\end{array}$ \\
\hline Old people have too much influence. & $\begin{array}{l}48.2 \% \\
\text { (38301 in } \\
79551)\end{array}$ & $\begin{array}{l}43.7 \% \\
(27905 \text { in } \\
63844)\end{array}$ & $\begin{array}{c}66.2 \% \\
(10396 \text { in } \\
15707)\end{array}$ & $\begin{array}{c}65.2 \% \\
(7989 \text { in } 12260)\end{array}$ \\
\hline
\end{tabular}

(a) Algeria, Egypt, Ghana, Libya, Morocco, Nigeria, Rwanda, South Africa, Tunisia, and Zimbabwe.

(b) Without Egypt and Libya. 


\section{Table 2. Scenarios}

\#1. "Two individuals, with equal education, apply to a job in your organization. One is 28 years old, and the other is 45 years old. Which one would you hire?".

\#2. "Your organization is going to select, between two workers, one that will participate in a training program provided by a university. Both employees (one 29 years old, the other 56) show high performance. However, the older worker is more motivated to the training. Which one would you select?"

\#3. In a company from the food industry, two employees, with similar qualifications, perform administrative tasks. One is 56 years old and shows high performance. The other employee is 25 years old and shows lower performance. Because the company has to reduce costs, only one employee can stay. Which one would you dismiss?

\#4. Maria and António, whose CVs are very similar, apply to a job vacancy in your organization. Maria is 45 years old, and António is 28 years old. Which one would you hire: António or Maria? 
Table 3. Confirmatory factor analysis - completely standardized solution

\begin{tabular}{|c|c|c|c|c|}
\hline & $\begin{array}{l}\text { African } \\
\text { managers } \\
(\mathrm{n}=154) \\
\end{array}$ & $\begin{array}{l}\text { Portuguese } \\
\text { managers } \\
(n=134)\end{array}$ & $\begin{array}{l}\text { African } \\
\text { students } \\
(\mathrm{n}=108)\end{array}$ & $\begin{array}{l}\text { Portuguese } \\
\text { students } \\
(\mathrm{n}=138) \\
\end{array}$ \\
\hline $\begin{array}{l}\text { Conscientiousness and performance (Cronbach } \\
\text { Alpha) }\end{array}$ & $(0.76)$ & $(\mathbf{0 . 7 1})$ & $(0.66)$ & $(\mathbf{0 . 8 0})$ \\
\hline Older workers miss more work. & 0.49 & 0.46 & 0.26 & 0.62 \\
\hline Older workers have lower work performance. & 0.67 & 0.62 & 0.79 & 0.71 \\
\hline $\begin{array}{l}\text { Older workers are less willing to take } \\
\text { responsibilities at work. }\end{array}$ & 0.56 & 0.49 & 0.46 & 0.62 \\
\hline Older workers are less productive. & 0.90 & 0.78 & 0.70 & 0.83 \\
\hline $\begin{array}{l}\text { Older workers are less willing to make sacrifices } \\
\text { on behalf of the organization. }\end{array}$ & 0.55 & 0.60 & 0.57 & 0.62 \\
\hline Social capital and generosity (Cronbach Alpha) & $(0.71)$ & $(0.77)$ & $(\mathbf{0 . 8 1})$ & $(0.74)$ \\
\hline Older workers are more willing to help co-workers. & 0.65 & 0.62 & 0.64 & 0.67 \\
\hline $\begin{array}{l}\text { Older workers are able to develop more lasting } \\
\text { relationships with other people. }\end{array}$ & 0.79 & 0.76 & 0.72 & 0.71 \\
\hline Older workers are more cooperative. & 0.69 & 0.68 & 0.81 & 0.76 \\
\hline $\begin{array}{l}\text { Older workers wish to perform jobs more useful to } \\
\text { society. }\end{array}$ & 0.35 & 0.64 & 0.67 & 0.48 \\
\hline Adaptability (Cronbach Alpha) & $(0.79)$ & $(0.76)$ & $(0.74)$ & $(0.77)$ \\
\hline $\begin{array}{l}\text { Older workers are less able to adapt to new } \\
\text { situations. }\end{array}$ & 0.86 & 0.80 & 0.75 & 0.76 \\
\hline $\begin{array}{l}\text { Older workers take longer to become competent in } \\
\text { the performance of a new job. }\end{array}$ & 0.73 & 0.74 & 0.80 & 0.83 \\
\hline Older workers are more resistant to change. & 0.68 & 0.62 & 0.47 & 0.59 \\
\hline \multicolumn{5}{|l|}{ Fit indices } \\
\hline Chi-square & 95.62 & 72.97 & 55.71 & 67.48 \\
\hline Degrees of freedom & 51 & 51 & 51 & 51 \\
\hline RMSEA & 0.08 & 0.06 & 0.03 & 0.05 \\
\hline Standardized RMR & 0.07 & 0.07 & 0.07 & 0.07 \\
\hline Goodness of fit index & 0.91 & 0.92 & 0.92 & 0.92 \\
\hline Comparative fit index & 0.92 & 0.95 & 0.99 & 0.98 \\
\hline Incremental fit index & 0.92 & 0.96 & 0.99 & 0.98 \\
\hline
\end{tabular}


Table 4. Attitudes toward older workers, and decisions in scenarios - comparing African versus Portuguese participants

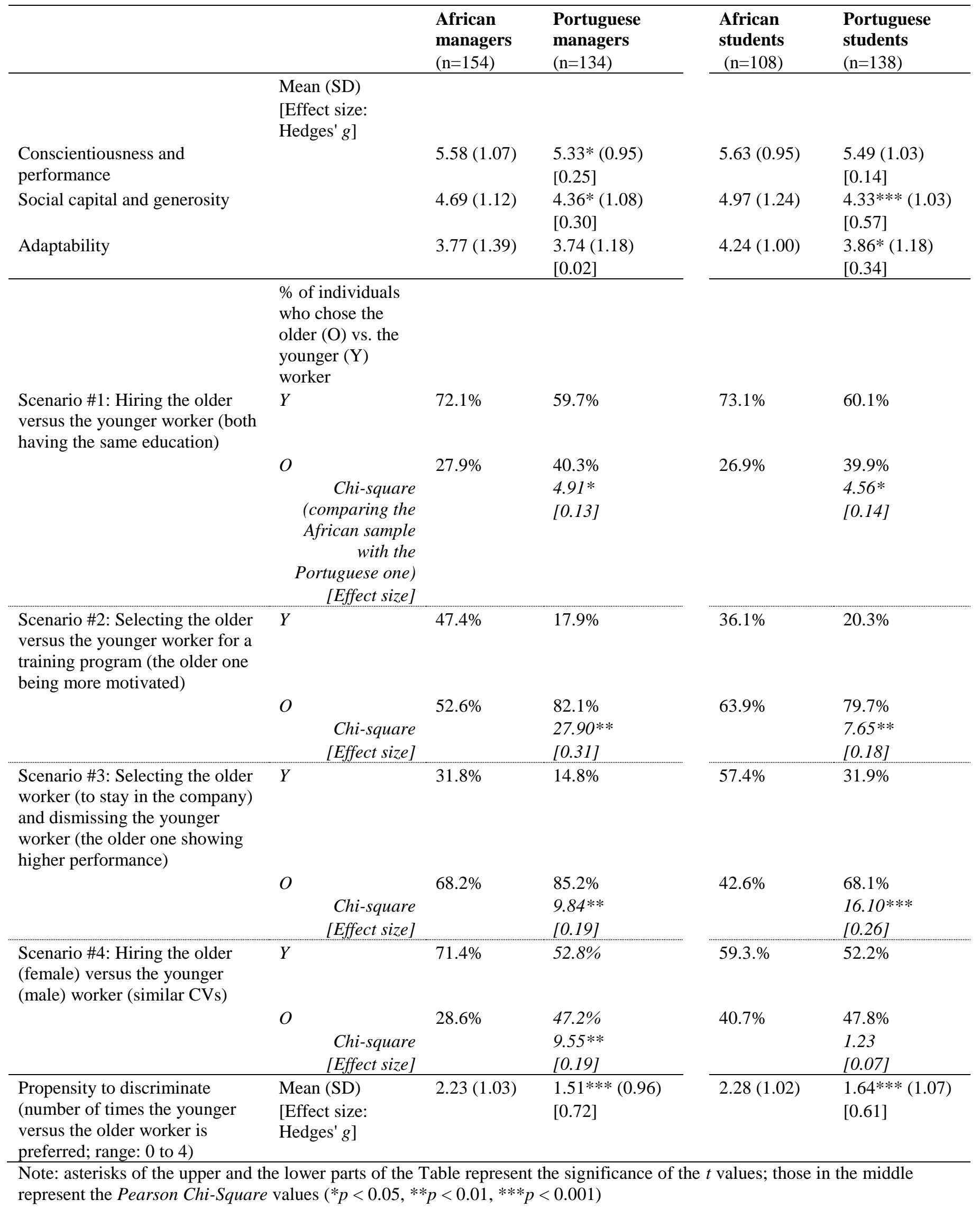


Table 5. Hierarchical regression analysis: How being African versus being Portuguese predicts attitudes toward older workers

\begin{tabular}{|c|c|c|c|c|c|c|c|c|}
\hline & \multicolumn{4}{|l|}{$\begin{array}{l}\text { Managers' } \\
\text { attitudes } \\
\text { toward older } \\
\text { workers }\end{array}$} & \multicolumn{4}{|l|}{$\begin{array}{l}\text { Students' } \\
\text { attitudes } \\
\text { toward older } \\
\text { workers }\end{array}$} \\
\hline & $\begin{array}{l}\text { Conscient. and } \\
\text { performance } \\
2^{\text {nd }} \text { step (f) }\end{array}$ & $\begin{array}{l}\text { Social capital } \\
\text { and generosity } \\
2^{\text {nd }} \text { step (f) }\end{array}$ & $\begin{array}{l}\text { Adaptability } \\
2^{\text {nd }} \text { step (f) }\end{array}$ & $\begin{array}{l}\text { Overall } \\
\text { attitude (e) } \\
2^{\text {nd }} \text { step (f) } \\
\end{array}$ & $\begin{array}{l}\text { Conscient. and } \\
\text { performance } \\
2^{\text {nd }} \text { step (f) }\end{array}$ & $\begin{array}{l}\text { Social capital } \\
\text { and generosity } \\
2^{\text {nd }} \text { step (f) }\end{array}$ & $\begin{array}{l}\text { Adaptability } \\
2^{\text {nd }} \text { step (f) }\end{array}$ & $\begin{array}{l}\text { Overall } \\
\text { attitude (e) } \\
2^{\text {nd }} \text { step (f) } \\
\end{array}$ \\
\hline Gender (a) & -0.09 & 0.09 & $-0.28 * * *$ & $-0.16^{* *}$ & -0.07 & -0.10 & -0.13 & -0.15 \\
\hline Age & $0.22 * *$ & $0.15^{*}$ & $0.15^{*}$ & $0.27 * * *$ & 0.03 & 0.11 & $0.16^{*}$ & $0.17 * *$ \\
\hline $\begin{array}{l}\text { Being a student of } \\
\text { management }(b)\end{array}$ & - & - & - & - & 0.01 & -0.06 & -0.07 & -0.09 \\
\hline Schooling & 0.04 & 0.00 & 0.09 & 0.08 & -0.15 & $0.18^{* *}$ & $-0.19 * *$ & -0.08 \\
\hline Tenure on the job & -0.08 & 0.03 & 0.09 & 0.04 & - & - & - & - \\
\hline Sector (c) & 0.10 & 0.11 & 0.01 & 0.11 & - & - & - & - \\
\hline $\begin{array}{l}\text { Being African versus } \\
\text { Portuguese (d) }\end{array}$ & 0.11 & $0.17 * *$ & 0.01 & $0.14^{*}$ & 0.12 & $0.21 * *$ & $0.17 *$ & $0.25 * * *$ \\
\hline $\mathrm{F}$ & $3.35^{* *}$ & $3.79 * * *$ & $6.21 * * *$ & $7.69 * * *$ & 1.45 & $6.71 * * *$ & $4.65^{* * *}$ & $6.34 * * *$ \\
\hline $\mathrm{R}^{2}$ & 0.07 & 0.08 & 0.12 & 0.14 & 0.03 & 0.12 & 0.09 & 0.11 \\
\hline $\mathrm{R}^{2}$ change & 0.01 & 0.03 & 0.00 & 0.02 & 0.01 & 0.03 & 0.02 & 0.05 \\
\hline Effect size (Cohen's f $\left.{ }^{2}\right)$ & 0.01 & 0.03 & 0.00 & 0.02 & 0.01 & 0.03 & 0.02 & 0.06 \\
\hline
\end{tabular}

$* p<0.05, * * p<0.01, * * * p<0.001$

(a) 0: female; 1: male; (b) 0: "No"; 1: "Yes" (c) 0: industry; 1: services; (d) 0: Portuguese; 1: African; (e) mean score of the three attitudes; (f) the 1 ${ }^{\text {st }}$ step includes the control variables (i.e., all variables except being African versus Portuguese) 
Table 6. How being African vs. Portuguese predicts decisions in scenarios (binary logistic regression) and the propensity to discriminate against older workers (linear regression) (managers' samples)

\begin{tabular}{|c|c|c|c|c|c|c|c|c|c|c|}
\hline & \multicolumn{2}{|c|}{$\begin{array}{c}\text { Scenario \#1 } \\
\text { Hiring the older worker (c) }\end{array}$} & \multicolumn{2}{|c|}{$\begin{array}{c}\text { Scenario \#2 } \\
\text { Selecting the older worker } \\
\text { for training (c) }\end{array}$} & \multicolumn{2}{|c|}{$\begin{array}{c}\text { Scenario \#3 } \\
\text { Selecting the older worker } \\
\text { and dismissing the younger } \\
\text { worker }\end{array}$} & \multicolumn{2}{|c|}{$\begin{array}{c}\text { Scenario \#4 } \\
\text { Hiring the older (female) } \\
\text { versus the younger (male) } \\
\text { worker }\end{array}$} & \multicolumn{2}{|c|}{$\begin{array}{l}\text { Propensity to discriminate } \\
\text { against older workers }\end{array}$} \\
\hline & $2^{\text {nd }}$ step & $3^{\text {rd }}$ step & $2^{\text {nd }}$ step & $3^{\text {rd }}$ step & $2^{\text {nd }}$ step & $3^{\text {rd }}$ step & $2^{\text {nd }}$ step & $3^{\text {rd }}$ step & $2^{\text {nd }}$ step & $3^{\text {rd }}$ step \\
\hline Gender (a) & $\begin{array}{l}-0.02 \\
(0.01)\end{array}$ & $\begin{array}{l}-0.16 \\
(0.27)\end{array}$ & $\begin{array}{l}0.23 \\
(0.61)\end{array}$ & $\begin{array}{l}-0.04 \\
(0.02)\end{array}$ & $\begin{array}{l}-0.14 \\
(0.20)\end{array}$ & $\begin{array}{l}-0.29 \\
(0.77)\end{array}$ & $\begin{array}{l}-0.21 \\
(0.51)\end{array}$ & $\begin{array}{l}-0.39 \\
(1.55)\end{array}$ & 0.01 & 0.07 \\
\hline Age & $\begin{array}{l}0.05^{*} \\
(5.95)\end{array}$ & $\begin{array}{l}0.05^{*} \\
(5.38)\end{array}$ & $\begin{array}{l}-0.08 * * * \\
(13.29)\end{array}$ & $\begin{array}{l}-0.10^{* * *} \\
(16.85)\end{array}$ & $\begin{array}{l}-0.01 \\
(0.17)\end{array}$ & $\begin{array}{l}-0.02 \\
(0.41)\end{array}$ & $\begin{array}{l}0.05^{*} \\
(5.15)\end{array}$ & $\begin{array}{l}0.05^{*} \\
(3.84)\end{array}$ & -0.04 & 0.00 \\
\hline Schooling & $\begin{array}{l}0.02 \\
(0.01)\end{array}$ & $\begin{array}{l}-0.04 \\
(0.03)\end{array}$ & $\begin{array}{l}0.31 \\
(1.82)\end{array}$ & $\begin{array}{l}0.17 \\
(0.56)\end{array}$ & $\begin{array}{l}0.06 \\
(0.07)\end{array}$ & $\begin{array}{l}-0.08 \\
(0.11)\end{array}$ & $\begin{array}{l}-0.40 \\
(2.89)\end{array}$ & $\begin{array}{l}-0.62 * \\
(5.91)\end{array}$ & 0.00 & 0.04 \\
\hline Tenure on the job & $\begin{array}{l}0.02 \\
(0.38)\end{array}$ & $\begin{array}{l}0.01 \\
(0.24)\end{array}$ & $\begin{array}{l}0.06 \\
(3.50)\end{array}$ & $\begin{array}{l}0.05 \\
(2.84)\end{array}$ & $\begin{array}{l}0.01 \\
(0.06)\end{array}$ & $\begin{array}{l}0.00 \\
(0.00)\end{array}$ & $\begin{array}{l}0.00 \\
(0.00)\end{array}$ & $\begin{array}{l}-0.01 \\
(0.03)\end{array}$ & -0.08 & -0.05 \\
\hline Sector (b) & $\begin{array}{l}-0.18 \\
(0.34)\end{array}$ & $\begin{array}{l}-0.12 \\
(0.15)\end{array}$ & $\begin{array}{l}-0.05 \\
(0.03)\end{array}$ & $\begin{array}{l}0.03 \\
(0.01)\end{array}$ & $\begin{array}{l}0.26 \\
(0.65)\end{array}$ & $\begin{array}{l}0.35 \\
(1.09)\end{array}$ & $\begin{array}{l}-0.21 \\
(0.45)\end{array}$ & $\begin{array}{l}-0.12 \\
(0.13\end{array}$ & 0.02 & -0.01 \\
\hline Consc. and performance & $\begin{array}{l}0.16 \\
(1.20)\end{array}$ & $\begin{array}{l}0.22 \\
(1.98)\end{array}$ & $\begin{array}{l}-0.22 \\
(2.46)\end{array}$ & $\begin{array}{c}-0.14 \\
(0.94)\end{array}$ & $\begin{array}{l}0.16 \\
(1.13)\end{array}$ & $\begin{array}{l}0.21 \\
(1.79)\end{array}$ & $\begin{array}{l}0.44 * * \\
(8.85)\end{array}$ & $\begin{array}{l}0.55 * * * \\
(11.77)\end{array}$ & -0.09 & $-0.14 *$ \\
\hline Social capital & $\begin{array}{l}0.10 \\
(0.73)\end{array}$ & $\begin{array}{l}0.16 \\
(1.70)\end{array}$ & $\begin{array}{l}-0.04 \\
(0.12)\end{array}$ & $\begin{array}{l}0.09 \\
(0.44)\end{array}$ & $\begin{array}{l}-0.09 \\
(0.49)\end{array}$ & $\begin{array}{l}-0.01 \\
(0.01)\end{array}$ & $\begin{array}{l}-0.11 \\
(0.75)\end{array}$ & $\begin{array}{l}0.00 \\
(0.00)\end{array}$ & 0.03 & -0.04 \\
\hline Adaptability & $\begin{array}{l}0.30^{*} \\
(6.55)\end{array}$ & $\begin{array}{l}0.30^{*} \\
(6.30)\end{array}$ & $\begin{array}{l}0.29^{*} \\
(6.27)\end{array}$ & $\begin{array}{l}0.30^{*} \\
(5.89)\end{array}$ & $\begin{array}{l}-0.22 \\
(2.94)\end{array}$ & $\begin{array}{l}-0.22 \\
(2.96)\end{array}$ & $\begin{array}{l}0.13 \\
(1.25)\end{array}$ & $\begin{array}{l}0.13 \\
(1.14)\end{array}$ & $-0.14^{*}$ & $-0.13^{*}$ \\
\hline $\begin{array}{l}\text { Being African vs. Portuguese } \\
\text { (c) }\end{array}$ & & $\begin{array}{l}-0.69^{*} \\
(5.71)\end{array}$ & & $\begin{array}{l}-1.58 * * * \\
(26.61)\end{array}$ & & $\begin{array}{l}-1.17 * * * \\
(11.44)\end{array}$ & & $\begin{array}{l}-1.18 * * * \\
(13.93)\end{array}$ & - & $0.38 * * *$ \\
\hline $\begin{array}{l}\text { Cox \& Snell } R^{2} \\
R^{2} \text { change }\end{array}$ & $\begin{array}{l}0.11 \\
0.05\end{array}$ & $\begin{array}{l}0.12 \\
0.01\end{array}$ & $\begin{array}{l}0.10 \\
0.04\end{array}$ & $\begin{array}{l}0.17 \\
0.07\end{array}$ & $\begin{array}{l}0.02 \\
0.02\end{array}$ & $\begin{array}{l}0.06 \\
0.04\end{array}$ & $\begin{array}{l}0.11 \\
0.05\end{array}$ & $\begin{array}{l}0.16 \\
0.05\end{array}$ & - & - \\
\hline $\begin{array}{l}\text { Nagelkerke } R^{2} \\
R^{2} \text { change }\end{array}$ & $\begin{array}{l}0.15 \\
0.05\end{array}$ & $\begin{array}{l}0.17 \\
0.02\end{array}$ & $\begin{array}{l}0.12 \\
0.02\end{array}$ & $\begin{array}{l}0.24 \\
0.12\end{array}$ & $\begin{array}{l}0.03 \\
0.02\end{array}$ & $\begin{array}{l}0.09 \\
0.06\end{array}$ & $\begin{array}{l}0.15 \\
0.07\end{array}$ & $\begin{array}{l}0.22 \\
0.07\end{array}$ & - & - \\
\hline $\begin{array}{l}\mathrm{F} \\
R^{2} \\
R^{2} \text { change }\end{array}$ & $\begin{array}{l}- \\
- \\
-\end{array}$ & $\begin{array}{l}- \\
- \\
-\end{array}$ & $\begin{array}{l}- \\
- \\
-\end{array}$ & $\begin{array}{l}- \\
- \\
-\end{array}$ & $\begin{array}{l}- \\
- \\
-\end{array}$ & $\begin{array}{l}- \\
- \\
-\end{array}$ & $\begin{array}{l}- \\
- \\
-\end{array}$ & $\begin{array}{l}- \\
- \\
-\end{array}$ & $\begin{array}{l}2.03 * \\
0.06 \\
0.04\end{array}$ & $\begin{array}{l}6.77 * * * \\
0.18 \\
0.12\end{array}$ \\
\hline $\begin{array}{l}\quad \text { Effect size }\left(\text { Cohen's f }{ }^{2}\right) \\
\text { Cox \& Snell } R^{2} \\
\text { Nagelkerke } R^{2} \\
R^{2}\end{array}$ & & $\begin{array}{l}0.01 \\
0.02 \\
-\end{array}$ & & $\begin{array}{l}0.08 \\
0.16 \\
-\end{array}$ & & $\begin{array}{l}0.04 \\
0.07 \\
-\end{array}$ & & $\begin{array}{l}0.06 \\
0.09 \\
-\end{array}$ & & $\begin{array}{l}- \\
- \\
0.15\end{array}$ \\
\hline
\end{tabular}

$* p<0.05, * * p<0.01, * * * p<0.001$

Values are the estimation coefficients. Between parentheses: Wald's statistic.

(a) 0: female; 1: male; (b) 0: industry; 1: services; (c) 0: Portuguese; 1: Africa 